\title{
Comparative Study Of Platforms For E-Learning In The Higher Education
}

José Mondéjar-Jiménez, University of Castilla-La Mancha, Spain

Juan-Antonio Mondéjar-Jiménez, University of Castilla-La Mancha, Spain

Manuel Vargas-Vargas,.University of Castilla-La Mancha, Spain

María-Leticia Meseguer-Santamaría, University of Castilla-La Mancha, Spain

\begin{abstract}
Castilla-La Mancha University has decided to implement two tools: WebCT and Moodle, "Virtual Campus" has emerged: www.campusvirtual.ulcm.es. This paper is dedicated to the analysis of said tool as a primary mode of e-learning expansion in the university environment. It can be used to carry out standard educational university activities in accordance with the guidelines set out by the new European Space for Higher Education. New needs continue to present themselves, not only with regard to the exchange of information and documents, but the complete and integrated management of teaching which is carried out using virtual environments and the Internet: $e$ learning.
\end{abstract}

Keywords: virtual campus, e-learning, virtual environment of learning

\section{INTRODUCTION}

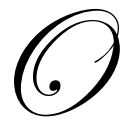

ver recent years, European universities in general, and Spanish universities in particular, have been in the midst of a profound remodelling of both their educational objectives and the methodology required to achieve them. The Bologna Declaration marks a starting point in this respect, strengthening the role of the students in their own learning process and encouraging the teaching staff to change their attitudes.

The new challenges facing university education in Europe arise from the need to use the new Information and Communication Technologies (ICTs). Thus, Spanish universities have launched various innovative initiatives in the area of teaching-learning processes to adapt both teaching and degrees to the European Space for Higher Education (ESHE).

The characteristics of the ICTs encourage the use of more constructionist methodologies based on the greater autonomy of the students in their work and on the supervisory role of the teaching staff. These new technologies mean that new types of learning and new learning environments can develop that facilitate the achievement of the previous objectives. In this respect, e-learning environments have proliferated in recent years, and they have evolved significantly. It seems then that the integration of ICTs in university education is essential, and to a certain extent, inevitable. But these technologies should only be adopted after a carefully considered process. There should not, according to the report Studies in the Context of the E-learning Initiative Virtual Models of European Universities (Pls Ramboll Management, 2004), be a radical break with the traditional model that risks confusing the agents involved (students and teaching staff).

These reflections, and the strong involvement of the University of Castilla-la Mancha (where the authors teach) in the use of ICTs and integration into the ESHE, have led the teaching staff there to use the Campus Virtual platform (https://campusvirtual.uclm.es/) to offer courses in the Business Administration and Management degree in the Social Sciences Faculty at Cuenca.

The current work briefly introduces the Campus Virtual tool, and describes how it is used in teaching courses. The work ends with the main conclusions and future lines of research. 


\section{THE CAMPUS VIRTUAL TOOL}

The group of Spanish universities known as G- $9^{1}$ is a non-profit association bringing together nine public universities that are the only public universities in their respective Autonomous Regions (Castilla-La Mancha, Extremadura, Oviedo, Cantabria, País Vasco, Pública de Navarra, Zaragoza, La Rioja and Illes Balears) in order to foster their academic activities.

The Campus Virtual (i.e., "Virtual Campus") has two applications. The first is the G-9 Shared Virtual Campus (Campus Virtual Compartido, CVC), which the universities use to share courses online. In the past academic year 2005/2006 more than 3,500 students enrolled on one of the 69 courses offered by this project (the majority "de libre configuración", i.e., courses that are not necessarily on the syllabus of the particular qualification being studied). This CVC is complemented by the Profesores Invitados por Red (Invited Lecturers Online) project, whereby students can attend a lecture given by an academic from another university by video-conference in order to complement the material given by their official course lecturer. In this way, any student can, from any computer with an internet link, attend a course offered by any of the nine participating universities, and do so entirely online.

A second application of Campus Virtual is to virtualise official courses in the existing syllabuses of each participating university. This option is the object of study of the current work, although the mechanism is similar to the CVC. Thus, teaching staff can complement the traditional, official education by using the Campus Virtual platform. In the academic years 2004/2005, 2005/2006, 2006/2007 and 2007/2008 the teaching staff of the University of Castilla-La Mancha (UCLM) have used the Campus Virtual tool voluntarily and above all - and more importantly - experimentally. Thus, this tool has coincided with the Red-C@mpus project ${ }^{2}$ in this university, which was the institutional tool that UCLM lecturers and students used by default. Campus Virtual is expected to replace Red-C@mpus in the next few years.

Figure 1: Homepage of Campus Virtual in UCLM

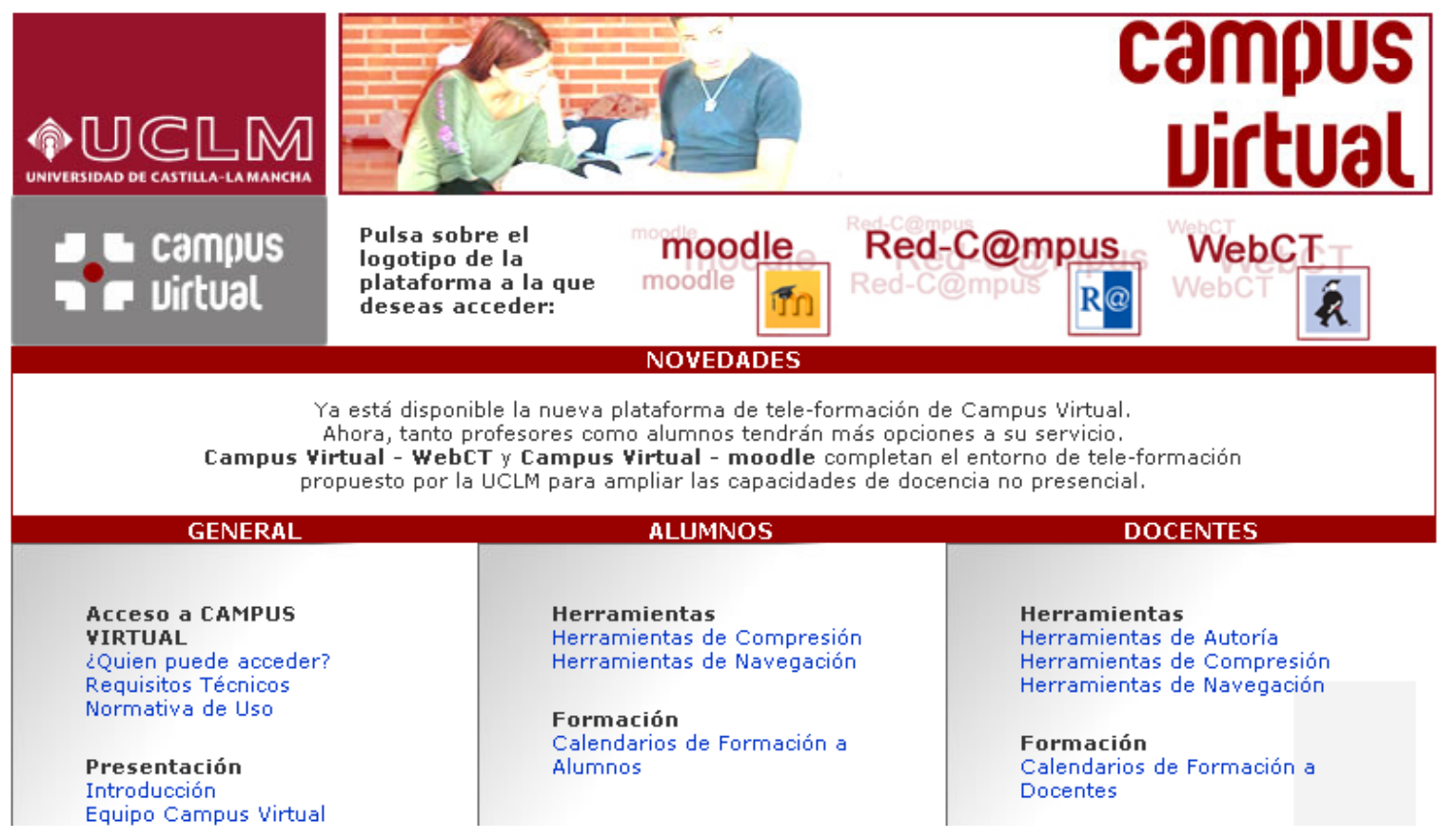

\footnotetext{
${ }^{1}$ This association has a full website: www.uni-g9.net.

${ }^{2}$ For a more detailed description of this project, see Mondéjar, Gómez and Lorenzo (2006).
} 
Thus, given the experimental nature of Campus Virtual in the University of Castilla-La Mancha during the academic years 2005/2006, 2006/2007 and 2007/2008, and in the framework of the Programa de Entrenamiento de Créditos ECTS (a programme to prepare students for courses with ECTS credits), which is run by the Social Sciences Faculty at Cuenca within the Business Administration and Management degree (BAM), the authors of the current work have used this tool in all the official courses they have given in both the first and second cycles (i.e., throughout the entire degree course), specifically:

Table 1: Experience of virtualised courses

\begin{tabular}{|c|c|c|c|}
\hline Course & Year/Semester & Speciality & Character \\
\hline Introduction to marketing & 1/Second & BAM & Core \\
\hline Descriptive statistics & 2/First & BAM & Core \\
\hline Probabilistic modelling & 3/First & BAM & Core \\
\hline Inferential statistics & 3/Second & BAM & Core \\
\hline Principals of marketing & 4/First & BAM & Core \\
\hline Commercial distribution & 4/First & BAM & Optional \\
\hline Statistical data analysis & 4/First & BAM & Optional \\
\hline Commercial management & 4/Second & BAM & Core \\
\hline Statistical quality control & 4/Second & BAM & Optional \\
\hline Market research & 4/Second & BAM & Optional \\
\hline
\end{tabular}

The home page of Campus Virtual (Figure 1) includes the following information, divided into three sections:

- General: who can access the site, technical requirements, regulations for use, and presentation of Campus Virtual and team behind it.

- $\quad$ Students (Alumnos): compression tools, navigation tools, educational calendar.

- $\quad$ Teaching staff (Docentes): authoring tools, compression tools and navigation tools, educational calendar for teaching staff, description and types of virtual workspace (EVT).

All members of the university community have access to Campus Virtual, specifically the following groups: students, teaching and research staff, and administration and services staff. The characteristics, functions available and permissions of each group differ depending on the course and on the individual's role in the course. All students are given a password when they enrol on any official course at the University of Castilla-La Mancha, giving them access to all the course material as their lecturers virtualise it. Other students can only access the material that is available in the permanent virtual spaces.

\section{DEVELOPMENT OF VIRTUAL COURSES}

After virtualising the course and generating a virtual workspace through the WebCT platform, the lecturer is responsible for updating the content. The lecturer is consequently the only administrator of the course. 
Figure 2: Example of virtualised courses

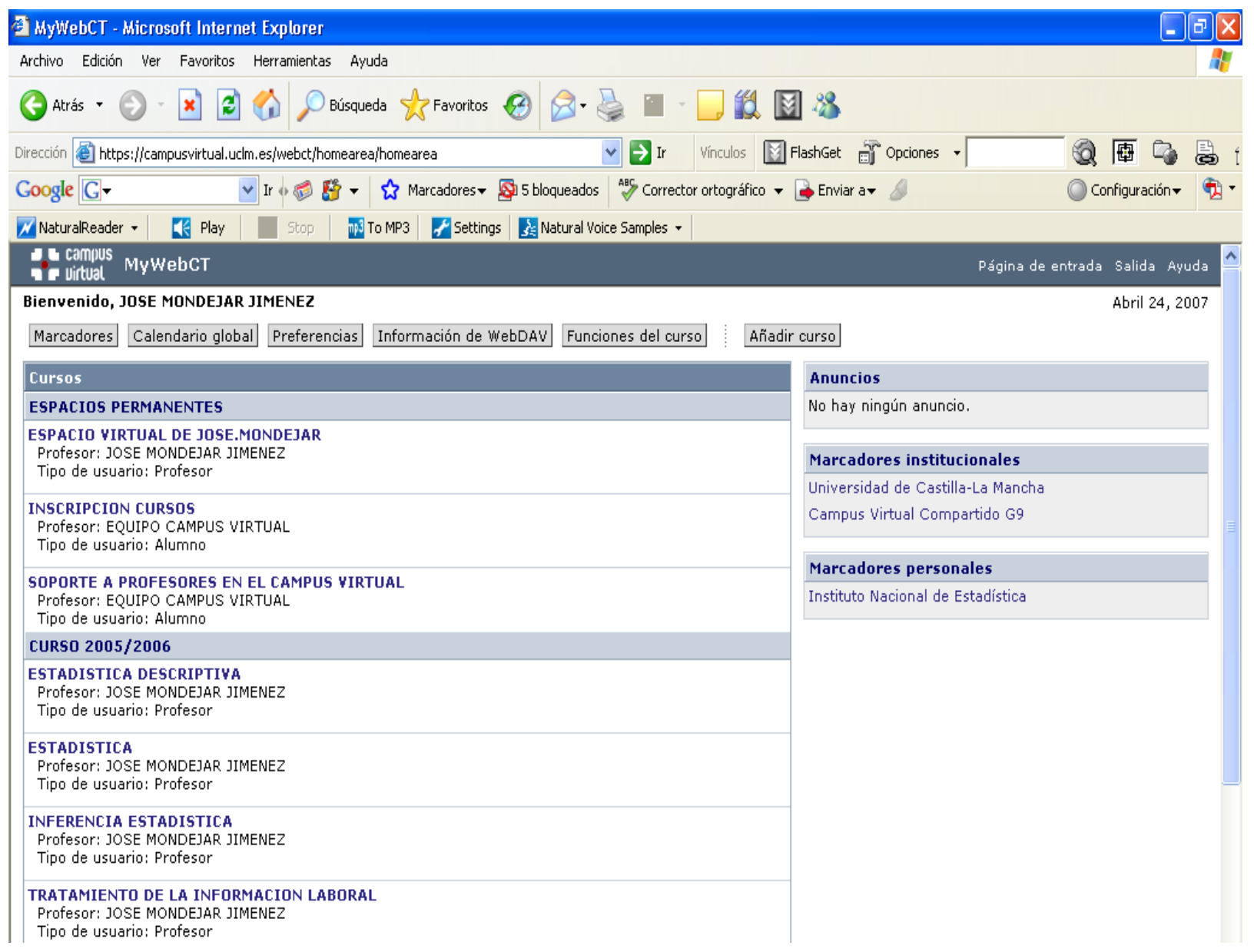

Looking more closely at the lecturer's virtual space, the following tools can be found in the different menus ${ }^{3}$ :

1) Start (Inicio): the point of entry into the course.

2) Course guide (Guía docente): which contains information about the course content, its objectives, the lecturer's bibliography and contact details (location of office, contact telephone number, e-mail, contact timetable, etc.). These guides have been produced adapting the course to the European Credit Transfer System (ECTS) ${ }^{4}$.

\footnotetext{
${ }^{3}$ From the second semester of academic year 2006/2007 this can also be done by Moodle. The authors gave their courses with WebCT in the past two years because the open source software did not work at first.

${ }^{4}$ These guides are produced within the framework of the teaching innovation project for the elaboration of teaching guides of year-1 and - 2 courses in the Business Administration and Management degree and the diploma in Labour Relations.
} 


\section{Figure 3: Menu of a course}

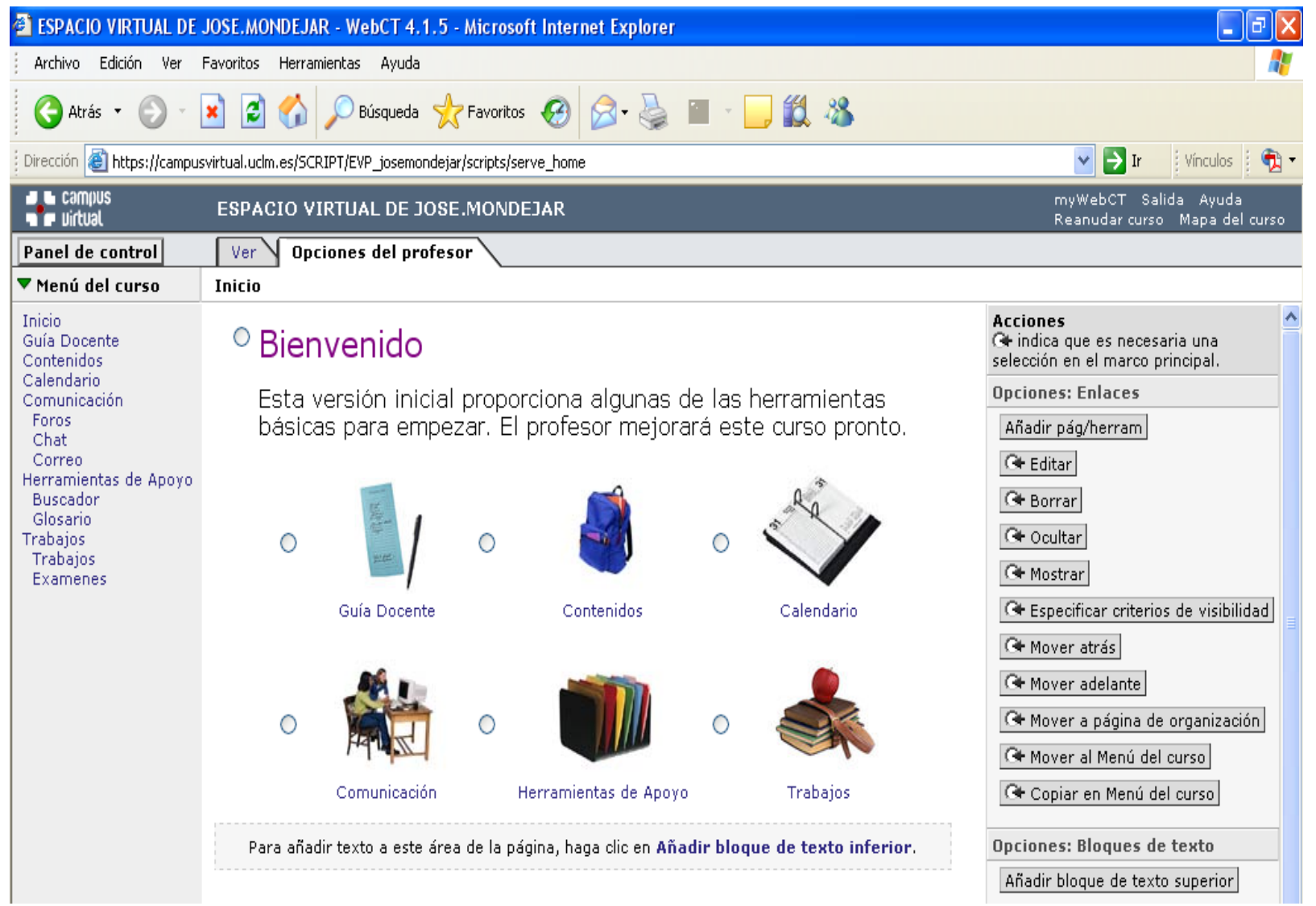

3) Contents (Contenidos): this section includes presentations of the course topics, and exercises and practice problems to resolve and hand in as the course progresses. Students are recommended to use the communication tools for the practice problems (see point number 5). Figure 4 shows an example of a virtual course for academic year 2006/2007. 


\section{Figure 4: Contents of Descriptive Statistics course}

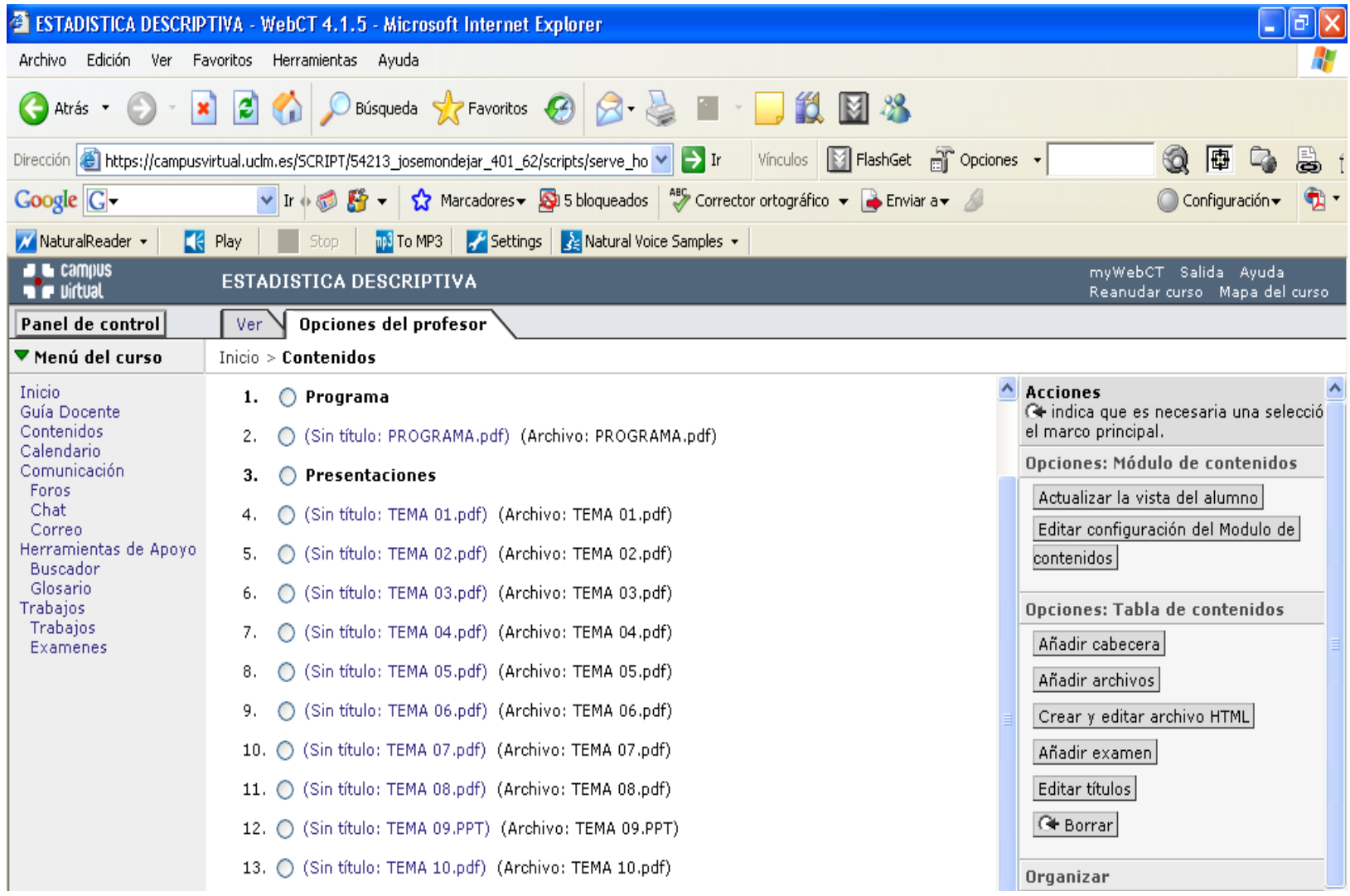

4) Calendar (Calendario): the academic calendar contains all the important dates on the course, such as classes in the computer room, deadlines for handing in the practice problems, when students have to present their work publicly, and other important dates for the students. 
Figure 5: Communication tools

\section{ESTADISTICA DESCRIPTIVA - WebCT 4.1.5 - Microsoft Internet Explorer}

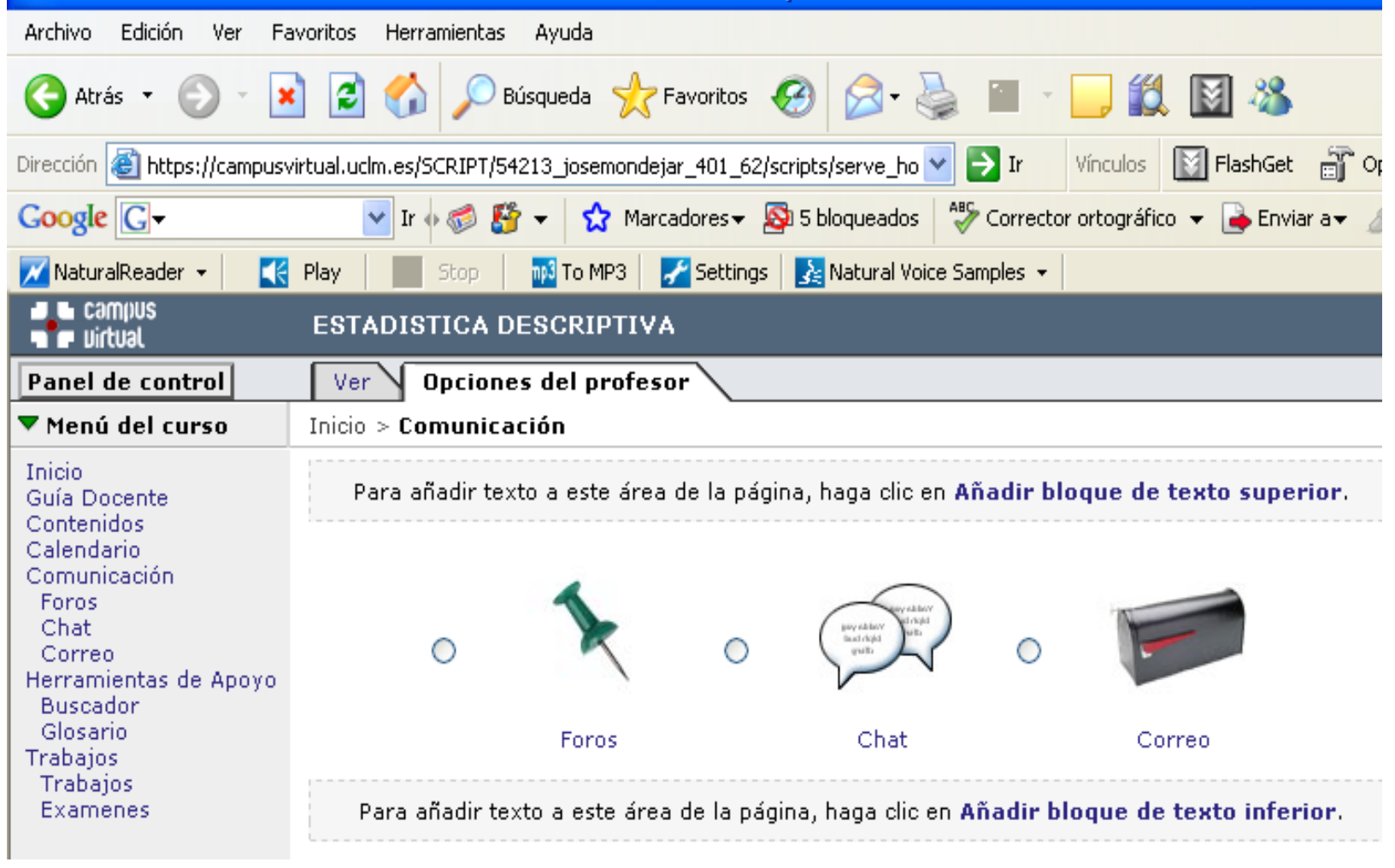

5) Communication (Comunicación): this section includes various tools: e-mail, forum and chat. Chat has special rooms for debating subjects, organised by topics or groups, or general rooms where students can contact other students studying the same course in different UCLM campuses, or students studying different courses or specialities. Students use all the communication tools in the different courses: e-mail for sending responses to the practice problems; the forum for resolving the practice problems, since students can send their queries to the forum, to which their own classmates respond (or the lecturer if no solution is given in a particular time period); and chat, where students can discuss the course or other questions. It should be noted that the lecturer receives a copy of both the chat and the forum.

6) Support tools (Herramientas de apoyo): includes a search engine and a glossary of terms necessary to understand the course, which the lecturer updates in the first few weeks of the course.

7) Work (Trabajos): this gives students the option to make their work visible to their classmates (students sometimes evaluate each other), and do virtual exams. Students can do work or tests from the faculty's computer room or even from home. Deadlines for completing exams can be included. Due to their complexity, and the fact that students can get very nervous when doing tests, only multi-choice tests have been done, with the aim being to remove some theoretical content from the final exam. The students could possibly do their final exam through WebCT, but frequent connection problems mean that they must all do this simultaneously from the faculty computer rooms and not from their homes. 


\section{Figure 6: Basic control panel}

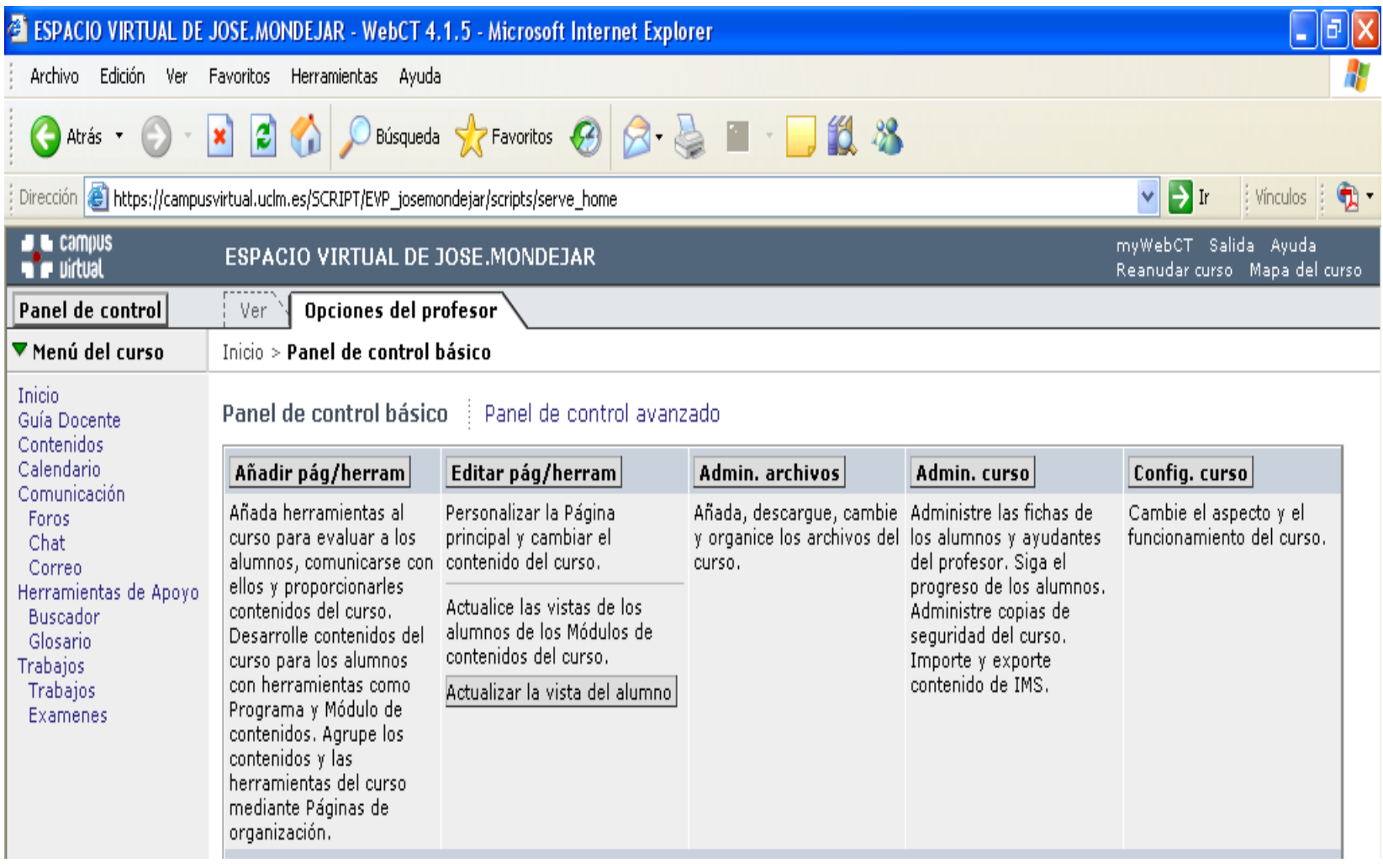

Finally, figures 6 and 7 show the basic and advanced teacher's control panel, where the lecturer can make technical and aesthetic changes to the presentation of the course material. 


\section{Figure 7: Advanced control panel}

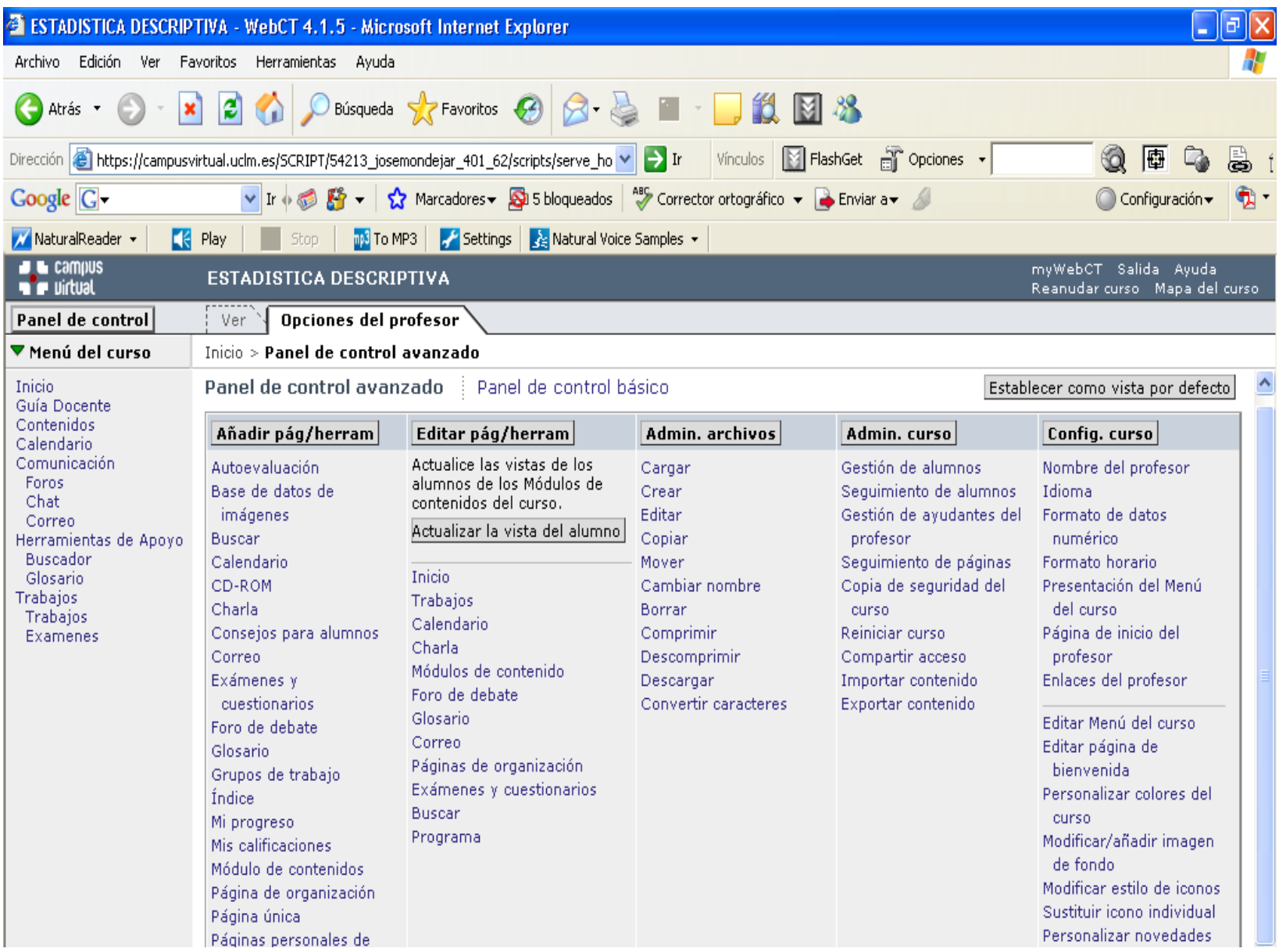

\section{CONCLUSIONS}

E-learning is a new type of education that aims to combine new technologies with traditional education. It perfectly suits the demands of today's students and the recommendations of the European Space for Higher Education. E-learning also enables students of any age to access university education, and class attendance is no longer one of the fundamental requirements for the student. Thus, e-learning does not necessarily have to compete with or substitute for presence-based education: the two can be perfectly complementary.

The final objective of all e-learning programmes should be that the students learn effectively, for which they must use the tool correctly and the technical system must be adequate. Looking at the Campus Virtual tool more specifically, the following evaluation is based on the authors' experience of teaching their subjects over the past three years. The main gains for both students and teaching staff are as follows:

- $\quad$ Register and control of students improves.

- $\quad$ Student-lecturer communication improves.

- $\quad$ The students are encouraged to interrelate with their classmates, using the communication tools to help each other.

- $\quad$ Both teaching staff and students have quicker and more effective access to information.

- Improves students' expectations about their results. 
- $\quad$ Considerably superior to the tool previously used by the University (Red-C@mpus).

The University of Castilla-La Mancha also aims to train users to use the tool. For this purpose, it has developed a full training programme for both students and teaching and research staff to learn the skills and competences required to use the tool correctly.

Clearly, the positive results of the "training plans" developed in the past three academic years provide the basis for optimism for the future, particularly in the light of ESHE recommendations to use ICTs and new teachinglearning procedures. In this respect, the authors consider that the University of Castilla-La Mancha is making good progress in adapting to this new higher education space in the framework of the European Union.

\section{AUTHOR INFORMATION}

\section{José Mondéjar-Jiménez:}

European PhD in Economics and Degree in Business Administration by University of Castilla-La Mancha. Degree in Advanced Studies in Statistics at the same university. Assistant Professor in Statistics at Statistics Department. Faculty of Social Sciences of Cuenca. University of Castilla-La Mancha (Spain).

Research Interest: E-learning, tourism and state-space models.

\section{Juan-Antonio Mondéjar-Jiménez:}

$\mathrm{PhD}$ and Degree in Business Administration by University of Castilla-La Mancha. Degree in Advanced Studies in Marketing at the same university. Assistant Professor in Marketing at Business Administration Department. Faculty of Social Sciences of Cuenca. University of Castilla-La Mancha (Spain).

Research Interest: E-learning, consumer behavior, price perception and tourism marketing.

\section{Manuel Vargas-Vargas:}

$\mathrm{PhD}$ in Economics by University of Castilla-La Mancha and Degree in Mathematics by University of Granada. Associate Professor in Statistics at Statistics Department. Faculty of Social Sciences of Cuenca. University of Castilla-La Mancha (Spain).

Research Interest: E-learning, tourism and state-space models.

\section{María-Leticia Meseguer-Santamaría:}

Degree in Business Administration by University of Castilla-La Mancha. Assistant Professor in Statistics at Statistics Department. Faculty of Economics and Business Administration of Albacete. University of Castilla-La Mancha (Spain).

Research Interest: E-learning, tourism and state-space models.

\section{REFERENCES}

1. Bayot, A.; Mondéjar, J.; Mondéjar, J.A.; Monsalve, F. and Vargas, M. (2005). The Difficulties of Learning Concepts in the Social Sciences. En Misztal, M. and M. Trawinski (eds.) Studies in Teacher Education: Psichopedagogy (pp. 242-258). Wydawnictwo Naukowe Akademii Pedagogicznej: Kraków.

2. Clegg, S.; Hudson, A. and Steel, J. (2003): The Emperor's New Clothes: Globalisation and e-Learning in Higher Education. British Journal of Sociology of Education, vol. 24 (1), pp. 39-53.

3. Koohang, A. and Harman, K. (2005): Open Source: A Metaphor for E-Learning. Informing Science Journal, vol. 8, pp. 74-86.

4. Levy, Y. (2007): "Comparing dropouts and persistence in e-learning courses". Computers \& Education, vol. 48 (2), pp. 185-204.

5. Mondéjar Jiménez, J. A., Gómez Borja, M.A. and Lorenzo Romero, C. (2006). Red-C@ mpus: una herramienta de apoyo en la implantación de metodologías ECTS en la Universidad de Castilla-La Mancha. I Jornadas Nacionales de Intercambio de Experiencias Piloto de Implantación de Metodologías ECTS, Universidad de Extremadura, Badajoz. 
6. Mondéjar Jiménez, J.; Mondéjar Jiménez, J.A. and Vargas Vargas, M. (2006). Implantación de la metodología e-learning en la docencia universitaria: una experiencia a través del proyecto Campus Virtual, Revista Latinoamericana de Tecnología Educativa, 5 (1), 59-71. Available in: http://campusvirtual.unex.es/cala/editio/

7. Mondéjar, J.; Vargas, M. and Mondéjar, J.A. (2007). Impacto del uso del e-learning en las actitudes hacia la estadística, Revista Latinoamericana de Tecnología Educativa, 6 (2), 31-47. Available in: http://campusvirtual.unex.es/cala/editio/

8. Mondéjar, J. A.; Mondéjar, J. and Vargas, M. (2007). Docencia virtual en universidades presenciales: experiencia en la universidad de Castilla-La Mancha, Revista Iberoamericana de Educación a Distancia, 10 (2), pp. 207-228.

9. Petrova, K. (2007): Mobile learning as a mobile business application. International Journal of Innovation and Learning, vol. 4 (1), pp. 1-13.

10. Pls Ramboll Management (2004). Studies in the Context of the E-learning Initiative:Virtual Models of European Universities (LOT 1). Draft Final Report to the EU Commission, DG Education \& Culture Virtual Models of Universities. Available in: www.elearningeuropa.info/extras/pdf/virtual_models.pdf

11. Selim, H.M. (2007): E-learning critical success factors: an exploratory investigation of student perceptions. International Journal of Technology Marketing, Vol. 2 (2), pp. 157-182.

12. Slavin, R.E. (1991). Group rewards make groupwork work, Educational Leadership, 48, 89-91.

13. Valverde Berrocoso, J. (2002). Herramientas de comunicación sincrónica y asincrónica. En Cabero, J. and Aguaded, J.I. Educar en red: Internet como recurso para la educación, (pp. 57-81). Málaga: Aljibe.

14. Walters, L. S. (2000). Four Learning Models, Harvard Education Letter's Research Online, Disponible en: http://www.edletter.org/past/issues/2000-mj/models.shtml.

\section{NOTES}




\section{NOTES}

